University of Nebraska - Lincoln

DigitalCommons@University of Nebraska - Lincoln

Agronomy \& Horticulture -- Faculty Publications

Agronomy and Horticulture Department

$9-1952$

\title{
Effects of Excessive Natural Mulch on Development, Yield, and Structure of Native Grassland
}

J. E. Weaver

University of Nebraska-Lincoln

N. W. Rowland

Follow this and additional works at: https://digitalcommons.unl.edu/agronomyfacpub

Part of the Plant Sciences Commons

Weaver, J. E. and Rowland, N. W., "Effects of Excessive Natural Mulch on Development, Yield, and Structure of Native Grassland" (1952). Agronomy \& Horticulture -- Faculty Publications. 445. https://digitalcommons.unl.edu/agronomyfacpub/445

This Article is brought to you for free and open access by the Agronomy and Horticulture Department at DigitalCommons@University of Nebraska - Lincoln. It has been accepted for inclusion in Agronomy \& Horticulture -Faculty Publications by an authorized administrator of DigitalCommons@University of Nebraska - Lincoln. 


\title{
EFFECTS OF EXCESSIVE NATURAL MULCH ON DEVELOPMENT, YIELD, AND STRUCTURE OF NATIVE GRASSLAND ${ }^{1,2}$
}

\author{
J. E. WEAVER AND N. W. ROWLAND
}

\section{Introduction}

Prairie vegetation is so universally mowed, grazed, or burned that little information has been recorded on its behavior under complete protection. Climax grassland, when grazed lightly or even moderately, may retain essentially its natural composition over extremely long periods $(16,18)$. But aside from observation there is little information upon the unusual and rare phenomenon of complete protection of grassland from disturbance over a considerable period of time.

In their monograph on the prairie, WEAVER and FitzPATRICK (14) stated: "Practically all of the prairies have been mowed annually, some for a period of more than fifty years. It has been repeatedly demonstrated that removal of the plant cover after it is mature has no harmful effect upon the vegetation. After the mowing is done close to the soil surface, there still remains 2.5 to 3 inches (often more on lowland) of unmowed stubble with dead basal leaves, among which accumulates fallen debris during 'hay making,' as well as the late autumnal growth. Undoubtedly the removal of the plants does have an effect not only upon the quantity of organic material that would ultimately return to the soil but also upon the density and composi-

\footnotetext{
${ }^{1}$ Contribution no. 159 from the Department of Botany, University of Nebraska.

2 This study was aided by a grant from the University Research Council, University of Nebraska, Lincoln, Nebraska.
}

tion of the plant cover." The mulch in annually mowed prairies may have a dry weight of 50-225 gm. per square meter on uplands and over 1,000 gm. on lowlands (15).

Experiments over a period of only 3-5 years by WeAver and FItzPatrick (14) have shown that the accumulation of debris greatly retards growth in spring. The soil warms more slowly since it does not receive the usual insolation. Not only is there an actual diminution of basal cover, but also certain of the smaller and earlier species are greatly handicapped in growth and tend to disappear. Thus, occasional fires every 2-3 years renovate unmowed prairies and are distinctly beneficial if they occur in spring before growth is renewed. Fires were undoubtedly frequent in prehistoric times, and the enormous herds of bison trampled down the grass, at least locally.

SAMPSON (9), working in the prairies of Illinois, stated: "Occasionally local areas may be found that are seldom disturbed by man. It is in these least disturbed tracts where the dead grass remains from year to year that the dominant plants maintain their purest stand. The secondary species become insignificant, being represented only as scattered individuals here and there. ..."

Curtis and PARTCH (4), from their experiments on the effect of fire, clipping, and fertilization on transplanted sods of Andropogon gerardi, concluded that the most important factor affecting flowering was the presence of old litter on the 
crowns. "Removal of this cover by either fire or clipping brought about a sixfold increase in flower production and a $60 \%$ increase in plant height." Where the litter was not removed from dense stands, new growth was delayed in the spring as much as 3-4 weeks. It seems probable that removal of the mulch permitted the plants to begin growth early and to build up a carbohydrate reserve before the normal period of flower primordium initiation (4).

An excellent review of the literature on natural mulches of grassland has recently been made by Dyksterhuis and Schmutz (5). They emphasized the great importance of mulches but pointed out that there has evidently been no earlier research dealing specifically with natural mulches of grassland. "Despite the profound importance of natural mulches in promoting infiltration of rainfall, in prevention of erosion, and in general maintenance of normal plant-soil-water relations, there are virtually no quantitative data concerning amounts or effects on natural grassland" (5).

\section{Observations}

\section{THE ABANDONED ROAD}

During a study of a large native pasture by Weaver and Tomanek (18) it was found that an abandoned road bounded it on the south. The natural vegetation of this road appeared to be in marked contrast with that of the pastures which adjoined it on both sides as well as with that of an annually mowed native prairie which also extended many rods along its northern border. There was an unusual abundance and rank growth of certain coarser prairie grasses, an almost complete absence of many species normally conspicuous in prairie, and a very deep mulch which had accumulat- ed through several years. The time of abandonment of the road, the absence of fires, and the lack of use of the land for hay or by grazing animals were ascertained from farmers who had lived nearby for 20-50 years. The steeply rolling topography (fig. 1) and the need for upkeep of several culverts were the causes for abandonment 15 years ago.

This road is located 6.5 miles north and 2 miles west of the University of Nebraska in Lincoln. The position of its western one-fourth mile is now marked only by a fence, since the sod was broken, and the soil is under cultivation. The grass on a part of the eastern one-fourth is sometimes cut for hay. It is separated from the central half-mile by a deep ditch. Thus, this part is well protected from disturbance. The road runs along the sides of hills which are 50-100 feet high. The land in the central portion has slopes of $3.5 \%$ to more than $17 \%$. Ruts 3-5 inches deep and 12 inches wide still mark the center of this roadway, which is $\mathbf{5 6 . 5}$ feet wide. Sometimes a second track paralleled the original one. The roadsides have probably never been much disturbed since the pastures were fenced many years ago. Exceptions occurred in the central part near two ravines. Here the surface soil had been removed from the steep banks to fill the bottoms of the ravines over the wooden culverts, long since decayed. Sufficient time has elapsed for climax vegetation to be re-established even in these excavated portions and fills. But with these wet areas and banks and the hydric and mesic lowland vegetation which covers them this paper is not concerned. One feature of the upland vegetation, however, should be made clear. Cattle in the rather low-grade pasture south of the road had regularly reached through the fence above a 3-foot, woven-wire base 
and grazed the vegetation rather closely in a strip 3-4 feet wide. This vegetation is much like that in the pasture, and only the usual thin mulch common to closely grazed grassland had accumulated here. On the north side dense vegetation continued undisturbed to the fence. prairie dropseed were intermixed with several other grasses which are often dominant in prairie. These data were obtained by mapping the types as each of several large portions of the abandoned road was laid off in squares 16.5 feet on a side.

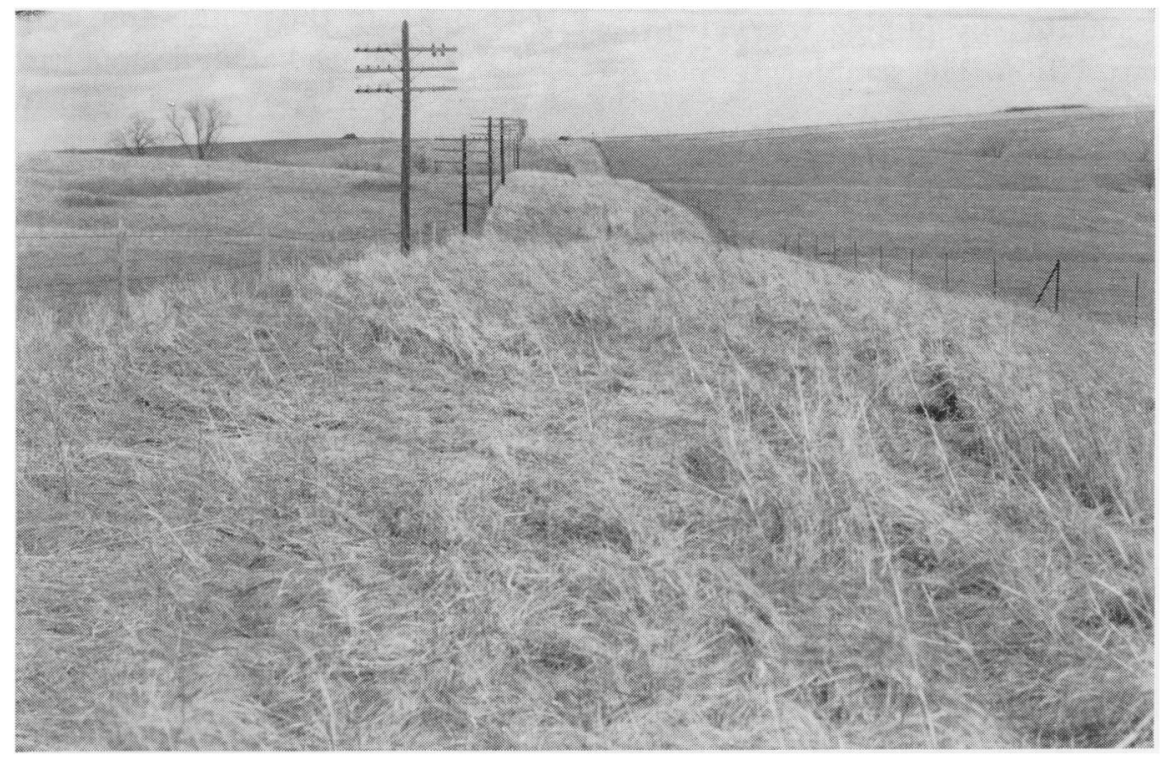

Fig. 1.-View looking eastward over rolling hills and dense vegetation in abandoned road, April, 1950. Steel posts on right are 1 rod apart.

\section{COMMUNITIES OR TYPES OF VEGETATION}

Examination of the area revealed four types of vegetation, each occurring in at least $85 \%$ and often in $98 \%$ pure stands. The most extensive was big bluestem (Andropogon gerardi). Within this sea of big bluestem occurred islands of prairie dropseed (Sporobolus heterolepis), sometimes large but often small. The switchgrass (Panicum virgatum) type was interspersed usually in pure or nearly pure stands over certain parts of the area. It was almost always surrounded by big bluestem. A fourth or mixed-grass type occurred in the few remaining places where big bluestem or this species and
Mapping was begun on the east slope of the central hill (fig. 1) and was continued westward over the rather flat top of this hill, a total distance of 17 rods (fig. 2). It was here that much of the experimental work was done. Ten rods of the slope in the foreground (nos. 18-27, fig. 1) were then mapped. A third strip, 10 rods long and west of the part included in the photograph, was selected as representative and also mapped. The big-bluestem community occupied $78 \%$ of the mapped area, prairie dropseed and switchgrass $9 \%$ and $8 \%$, respectively, and the mixedgrass type was found in only $5 \%$. 


\section{AMOUNT AND DISTRIBUTION OF MULCH}

In order to ascertain the amount of mulch, samples were taken at random in each type of vegetation. This was done on April 18, 1950. A heavy iron wheel was placed on the mulch, its rim inclosing exactly 5 square feet. With steel clippers the mulch was cut just outside the wheel and separated by pulling it away from the part within. The sample was then re-
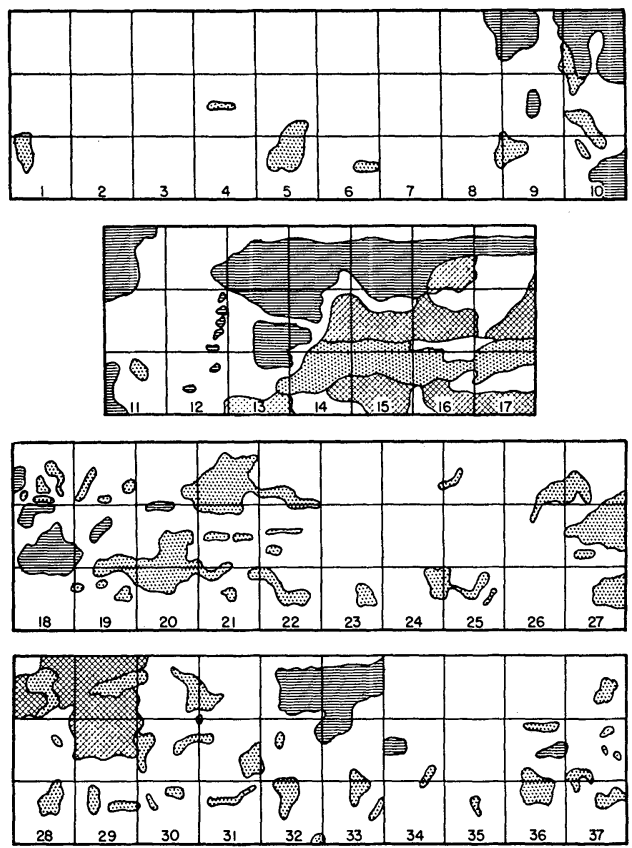

FIG. 2.-Map of representative portions of vegetation in abandoned road. Each minor unit is a square rod. Disturbed vegetation near south fence was not mapped. Unshaded portion represents areas occupied by big-bluestem type; dotted areas, prairie dropseed; horizontal lines, switchgrass; and crosshatch, mixed-grass type.

moved by hand, using the clippers as needed to cut dead stems of previous years close to the soil. The organic mulch was separated from the mineral soil without difficulty. After the mulch was air dried in the laboratory, it was torn apart and examined, so that no particles of soil or other foreign matter were weighed with the mulch.

The mulch included all the vegetable matter, in any stage of decay, from the plants of previous years. In the big-bluestem type it occurred only near the soil where the stems, leaves, etc., had fallen to form a layer 5.5-7 inches or more deep (figs. 3, 4). In the prairie-dropseed type, where the bunch had built up a basal column 2-4 inches above the soil, the widely spreading leaves formed a mulch which was thicker between the bunches than just above them. But in the switchgrass type the old stems usually remained standing for at least a year. By clipping the dead plants at the 5-inch level over sample areas of 10 square feet and weighing separately the dried material below and above this level, it was ascertained that approximately half of the total switchgrass mulch consisted of the stems, leaves, and panicles above 5 inches. Attached, dried leaves occurred abundantly only above a height of 2 feet.

There was a thick layer of mulch in all the types of vegetation (table 1). Many other measurements of depth were taken the following year. Rarely was the fallen mulch thinner than 3 inches, and in some places it was 1.0 inches thick (fig. 5). It reaches a maximum depth in winter and spring, by which time the dead plants of the previous summer had added new materials. By October, before it was thus much augmented, the constant decay of plant materials beneath added much organic matter to the soil. The mulch was then more compacted and thinner. The average amount of well-decayed or humic mulch (5) in the samples in table 1 was $30 \%$ by weight in big-bluestem type, and 25,15 , and $39 \%$ in switchgrass, prairie dropseed, and the mixed-grass type, respectively. 
SoIL

The Carrington loam soil is a zonal Prairie soil developed on leached glacial till. It has a dark grayish-brown, granular A horizon 10-12 inches deep, a yellowish-brown, clayey B horizon, which at evidence of accumulation of dust on the soil surface. The upper 3 inches of soil had a fine-crumb structure- that is, the soil aggregates were soft and porous. Sometimes this structure extended to 4 inches in depth. Below this level the soil

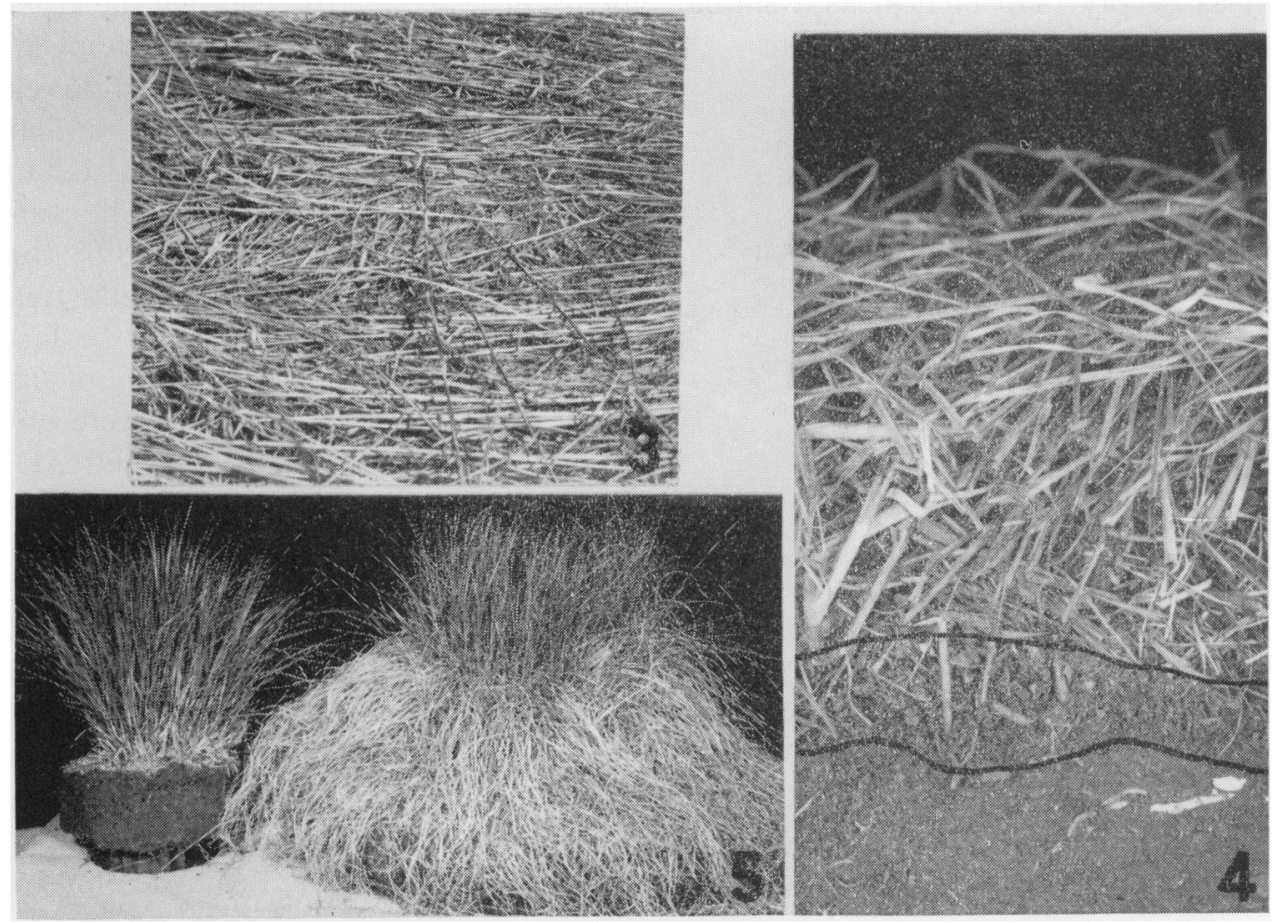

Figs. 3-5.-Fig. 3, mulch of big bluestem 8 inches thick covered with fallen flower stalks of previous year. April 18, 1950. Fig. 4, detail of mulch of big bluestem. Slightly decayed upper portion (litter) is 4-5 inches thick; well-decayed friable portion between lines (humic mulch) is about 2 inches deep. These are $A_{00}$ and $A_{0}$ horizons as designated by soil scientists. Beneath is mineral soil ( $A_{1}$ horizon) with rhizomes (white) near surface. Fig. 5, two bunches of prairie dropseed, May 23, 1951. Bases of stems are at same level. Mulch from bunch on left had been removed in early spring.

3-4 feet in depth gives way to the C horizon of glacial till. Although the calcium carbonate has been leached from the solum, and no free lime is found to a depth of about 5 feet, the $\mathrm{pH}$ is usually 6.5. The precipitation of about 27.5 inches annually moistens the soil deeply. Both surface and internal drainage are good.

In the abandoned road there was no had a medium-fine granular structure which was more aggregated. The differences between this soil and that in the adjacent pasture are not in texture (or size of particles) but in structure or composition. The grass roots extended upward clear to the surface of the mineral soil. The coarse roots of big bluestem and switchgrass, which were very abundant, pried the soil particles apart and pro- 
duced larger openings than did those of the fine-rooted bluegrass and blue grama in the pasture. A vast network of rhizomes also occurred in the surface layer. In the grazed but untrampled strip near the south fence it was found that a thrust by a 175-pound man sank a spade only half as deeply (4-5 inches) as a similar

\section{TABLE 1}

DEPTH OF MULCH (HEIGHT OF ERECT DEAD STEMS OF SWITCHGRASS); AIR-DRY WEIGHT (GM.) PER SAMPLE (5 SQ. FT.); AND CALCULATED TONS PER ACRE. MUlCh COLleCted APRIL 18, 1950

\begin{tabular}{|c|c|c|}
\hline $\begin{array}{l}\text { DертH } \\
\text { (IN.) }\end{array}$ & $\begin{array}{c}\text { DRY WEIGHT } \\
\text { (GM.) }\end{array}$ & $\begin{array}{c}\text { TONS PER } \\
\text { ACRE }\end{array}$ \\
\hline \multicolumn{3}{|c|}{ Big-bluestem type } \\
\hline $\begin{array}{l}6.5 \ldots \ldots \\
6.0 \ldots \\
6.0 \ldots \\
4.5 \ldots \ldots \\
7.0 \ldots \ldots \\
5.5 \ldots \ldots\end{array}$ & $\begin{array}{l}931 \\
861 \\
880 \\
751 \\
393 \\
570\end{array}$ & $\begin{array}{c}\ldots \ldots \\
\ldots \ldots \\
\ldots \ldots \\
7.02 \\
\ldots \ldots \\
\ldots \ldots\end{array}$ \\
\hline
\end{tabular}

Prairie-dropseed type

\begin{tabular}{l|l|l}
\hline & \\
$4.0 \ldots \ldots \ldots$ & 847 & $\ldots \ldots \ldots$ \\
$5.5 \ldots \ldots \ldots$ & 751 & $\ldots \ldots \ldots$ \\
$5.5 \ldots \ldots \ldots$ & 452 & $\ldots \ldots \ldots$ \\
$5.5 \ldots \ldots$ & 724 & 6.79 \\
$4.5 \ldots \ldots$ & 803 & $\ldots \ldots \ldots$ \\
$4.5 \ldots \ldots$ & 668 & $\ldots \ldots \ldots$ \\
\hline
\end{tabular}

Switchgrass type

\begin{tabular}{r|r|r}
\hline $56 \ldots \ldots \ldots$ & $9 . \ldots \ldots$ \\
$52 \ldots \ldots \ldots$ & $9 \ldots \ldots$ \\
$65 \ldots \ldots$ & 1,321 & $\ldots \ldots \ldots$ \\
$60 \ldots \ldots$ & 772 & $\ldots \ldots \ldots$ \\
\hline
\end{tabular}

Mixed-grass type

\begin{tabular}{r|r|r}
\hline & & \\
$3.5 \ldots \ldots \ldots$ & 635 & $\ldots \ldots \ldots$ \\
$3.5 \ldots \ldots \ldots$ & 717 & 5.71 \\
$4.0 \ldots \ldots \ldots$ & 537 & $\ldots \ldots \ldots$ \\
$4.5 \ldots \ldots \ldots$ & 488 & $\ldots \ldots \ldots$ \\
\hline
\end{tabular}

thrust in the heavily mulched portions of the road. The soil appeared even mellower and often more moist under switchgrass than under big bluestem.

ORGANIC MATTER AND NITROGEN.Samples for the determination of organic matter and nitrogen were secured to a depth of 7 inches, after clipping the vegetation at the soil surface and removing all organic mulch. Samples were also taken from an adjacent prairie, of similar southwest exposure and slope, which had been mowed once each year. The percentage of carbon was determined by the Smith-Weldon method of combustion (11) and this was multiplied by the factor 1.72 to obtain the percentage of organic matter. Nitrogen values were obtained by the GunNING method (1). Analyses were made by the Soils Division of the Department of Agronomy, University of Nebraska.

Amounts of both organic matter and nitrogen in the surface soil of the mowed prairie (table 2) are in close agreement with the average from several similar prairies where the samples were taken to a depth of 4 inches (10). The organic matter in the surface 1.5 inches of soil under the mulch of bluestem and switchgrass, respectively, exceeded that in mowed prairie by 2.11 and $1.46 \%$ of the dry weight of the soil. A similar difference at $1.5-3$ inches depth was $0.84 \%$ in bluestem; but the amount of organic matter at this level was slightly greater in mowed prairie than in switchgrass. However, at all other depths there was more organic matter in the mulched soil under bluestem. Amounts of nitrogen under the bluestem mulch were 0.095 , $0.053,0.028$, and $0.025 \%$ of oven-dry weight of soil in excess of those in mowed prairie. The smaller increases under the switchgrass mulch seem to indicate that 
this grass is not so effective as big bluestem in enriching the soil.

VOLUME-WEIGHT AND PORE SPACE.The volume-weight of a soil is the weight of oven-dry soil per unit volume. It is here expressed as grams per cubic centimeter. A volume-weight of 1.12 may be considered as typical for upland virgin prairie soil of medium texture (17). It is low in comparison with that of the second 6 inches (1.31) because of the high degree mulch was $61.7 \%$. It is believed that this high degree of porosity resulted mainly from the large amount of organic matter and the loosening action of roots and rhizomes, which were abundant even in the surface inch of soil.

EARTHWORMS.--Close examination of the surface soil showed some casts of earthworms. Since practically no earthworms had been observed in removing the mulch or in examining the soil profile,

TABLE 2

PERCENTAGE (OVEN-DRY-WEIGHT BASIS) OF ORGANIC MATTER AND NITROGEN IN SOILS OF ANNUALLY MOWED PRAIRIE AND OF PRAIRIE WITH 15 YEARS' ACCUMULATION OF ORGANIC MULCH

\begin{tabular}{|c|c|c|c|c|c|c|}
\hline \multirow[b]{2}{*}{$\begin{array}{l}\text { DEPTH } \\
\text { (IN.) }\end{array}$} & \multicolumn{3}{|c|}{$\%$ Organic Matter } & \multicolumn{3}{|c|}{$\%$ Nitrogen } \\
\hline & $\begin{array}{l}\text { Mowed } \\
\text { prairie }\end{array}$ & $\begin{array}{l}\text { Big- } \\
\text { bluestem } \\
\text { mulch }\end{array}$ & $\begin{array}{l}\text { Switch- } \\
\text { grass } \\
\text { mulch }\end{array}$ & $\begin{array}{l}\text { Mowed } \\
\text { prairie }\end{array}$ & $\begin{array}{l}\text { Big- } \\
\text { bluestem } \\
\text { mulch }\end{array}$ & $\begin{array}{l}\text { Switch- } \\
\text { grass } \\
\text { mulch }\end{array}$ \\
\hline $\begin{array}{l}0.0-1.5 \ldots \ldots \\
1.5-3.0 \ldots \ldots \\
3.0-5.0 \ldots \ldots \\
5.0-7.0 \ldots \ldots \ldots\end{array}$ & $\begin{array}{l}6.21 \\
4.97 \\
4.20 \\
3.65\end{array}$ & $\begin{array}{l}8.32 \\
5.81 \\
4.73 \\
4.35\end{array}$ & $\begin{array}{l}7.67 \\
4.87 \\
4.20 \\
3.82\end{array}$ & $\begin{array}{r}0.303 \\
.231 \\
.198 \\
0.180\end{array}$ & $\begin{array}{r}0.398 \\
.284 \\
.226 \\
0.205\end{array}$ & $\begin{array}{r}0.350 \\
.236 \\
.199 \\
0.185\end{array}$ \\
\hline
\end{tabular}

of granulation and the presence of a large amount of root material in the surface soil. The upper 3-inch layer of soil in the abandoned road under the heavy mulch of big bluestem was so porous that its volume-weight was 0.97 . Thus, less than a gram of soil occupied a cubic centimeter of volume.

The volume of prairie topsoil occupied by air and water-the pore space - often exceeds in amount that occupied by solid matter. Pore space is generally greater in fine-textured soils and those of high organic-matter content. It is increased by those processes which promote granulation, such as wetting and drying, freezing and thawing, and particularly the action of the roots and rhizomes of perennial grasses. The pore space in the loose upper 3 -inch layer of mineral soil under the careful studies were made. Early in August, blocks of soil about 6 inches square were removed to a depth of 7 inches. Each of these was placed separately in a half-square-meter pan, the soil was crumbled and worked over thoroughly, and the earthworms counted.

Twenty-one samples beneath the bigbluestem mulch contained only eighteen earthworms. Since one sample had eight and two others two and three, almost two-thirds of the samples had none. Other soil samples to a depth of 12 inches were without worms. The soil was moist but not too wet for good aeration. Its temperature was $71^{\circ}-72^{\circ} \mathrm{F}$. Numerous samples under the mulch of switchgrass gave similar results. In the bluegrass pasture, a few paces beyond the fence, ten samples revealed only seven earthworms. 
Thus, earthworms were not abundant.

These results are in striking contrast to those of Dyksterhuis and Schmutz (5). They found that the surface soil of a relict area of True Prairie near Fort Worth, Texas, unmowed and ungrazed for decades, was covered with a continuous layer of earthworm casts $0.25-1$ inch or more in depth. The largest quantity of natural mulch was associated with the greatest accumulation of these aggregates.

\section{EFFECT OF MULCH ON OTHER ENVIRONMENTAL FACTORS}

RAINFALL INTERCEPTION.-A cover of grass exerts a profound effect upon the water content of soil. Large amounts of water are held on the plants and evaporated into the air without reaching the soil. For example, CLARK (3) has shown that a thick stand of big bluestem withheld about two-thirds of the precipitation during heavy rains (1.2-1.8 inches) and as much as $97 \%$ of very light showers. When an inch of rain falls during an hour, big bluestem with fully developed foliage may intercept over fifty-three tons of water per acre (2). A thick cover of mulch is also capable of causing considerable loss of water to the soil in this manner.

Experiments were made to ascertain how much water was intercepted by the mulch. Places were selected at random in the big-bluestem type. After a small area of the grass had been cut above the mulch and discarded, a circular cardboard, 1 square foot in area was held firmly in place over the mulch. The mulch was then cut with hand clippers around the cardboard to the soil surface and the surrounding mulch pulled away from the sample. Two men with fingers widespread raised the part with intact leaves as a unit from the soil. The humic mulch was also collected, and the entire sample was taken to the laboratory and air dried. Six samples were secured on July 9.

Cylindrical, straight-walled pans, 1 square foot in area and 5 inches deep, with a small hole near the side on the bottom, were used in the experiment. Woven wire with 8 meshes per inch was placed on the bottom of the pan. After wetting the wire and pan and tilting them slightly so that excess water could drain away, the mulch was placed in the pan in its normal position. Water was added to the mulch by means of a spray syringe at a rate of 0.25 surface-inch in 30 minutes. It was added in equal amounts at 5-minute intervals, and the pans were covered between the sprayings. Water not held by the mulch drained into a small funnel placed in a bottle beneath the pan; the insides of both funnel and bottle were wetted before the experiments began. The amount of water intercepted by each of the samples of mulch was 58, 49, 49, 54, 56 , and $62 \%$, respectively, of the amount applied. This indicates that an average of more than half of a quarter-inch rain in 30 minutes would not reach the soil. Since no sample of the mulch was found to be thoroughly wet, further studies were made.

The percentage of water intercepted when 0.25 surface-inch was applied each half-hour and the part of a surface-inch held when the mulch was saturated are shown in table 3 . The results indicate that in long-continued rains, when the mulch becomes completely wet, as much as one-third inch of rain could be held above the soil and again evaporated into the air. Conversely, the mulch promoted infiltration of water into the soil as was shown experimentally.

INFILTRATION.-Studies were made in midsummer to ascertain the effect of the 
mulch upon rate of water penetration. The apparatus and method used were the same as those described by ROBERTSON (8). Cylinders made from 15 -inch sections of seamless steel tubing 4 inches in diameter and sharpened at one end were

TABLE 3

PERCENTAge OF 0.25 SURFACE-INCH OF WATER HELD BY THE MULCH THE FIRST AND SECOND HALF-HOUR AND TOTAL AMOUNT HELD WHEN SATURATED

\begin{tabular}{|c|c|c|c|}
\hline \multirow[b]{2}{*}{ Sample } & \multicolumn{2}{|c|}{ INTERCEPTION } & \multirow{2}{*}{$\begin{array}{c}\text { WATER HELD } \\
\text { BY SATURATED } \\
\text { MULCH } \\
\text { (\% SUR- } \\
\text { FACE-IN.) }\end{array}$} \\
\hline & $\begin{array}{c}\text { First } \\
30 \mathrm{~min} . \\
(\%)\end{array}$ & $\begin{array}{l}\text { Second } \\
30 \text { min. } \\
(\%)\end{array}$ & \\
\hline $\begin{array}{l}7 \ldots \ldots \ldots \\
8 \ldots \ldots \ldots \\
9 \ldots \ldots\end{array}$ & $\begin{array}{l}55 \\
50 \\
76\end{array}$ & $\begin{array}{r}12 \\
8 \\
23\end{array}$ & $\begin{array}{l}22 \\
17 \\
32\end{array}$ \\
\hline
\end{tabular}

forced into the soil vertically with a hydraulic jack to a depth of 14 inches. A coating of light motor oil inside and out, combined with the sharp cutting edge and the thinness of the wall of the cylinder reduced to a minimum the altering of the structure of the inclosed soil (17). It seemed desirable to ascertain the rate of percolation in closely adjacent soils which had not been covered with a mulch throughout the 15-year period. Bluegrass pasture occurred on both sides of the road, but here the effect of soil compaction by trampling entered in. Hence, it was decided to use as a control the grazed area just inside the fence where no trampling had occurred. The original bluestem near the fence had been closely grazed so frequently that it had probably been replaced long ago by bluegrass. Here the soil was mellow near the surface but much less so than that under big bluestem. Before the cylinders were sunk, the grass was clipped at a height of 2 inches and removed, and in the big bluestem all but a half-inch of the humic mulch was also removed. A constant head of a few millimeters of water was maintained in each of the four cylinders used in each sampling area. Results are shown in table 4.

TABLE 4

AMOUNT OF WATER (CC.) ENTERING THE SOIL IN 30-MINUTE PERIODS IN EACH OF EIGHT CYLINDERS

\begin{tabular}{|c|c|c|c|c|c|}
\hline \multirow{2}{*}{$\begin{array}{c}\text { HALF- } \\
\text { HOUR } \\
\text { PERIODS }\end{array}$} & \multicolumn{4}{|c|}{ NUMBER OF CYLINDER } & \multirow{2}{*}{ Av. } \\
\hline & 1. & 2 & 3 & 4 & \\
\hline & \multicolumn{5}{|c|}{ Soil under bluegrass } \\
\hline $\begin{array}{l}\text { 1st.... } \\
2 \mathrm{~d} \ldots \ldots \\
3 \mathrm{~d} \ldots \ldots \\
4 \mathrm{th} \ldots\end{array}$ & $\begin{array}{r}350 \\
15 \\
4 \\
4\end{array}$ & $\begin{array}{r}286 \\
24 \\
38 \\
38\end{array}$ & $\begin{array}{r}500 \\
190 \\
14 \\
15\end{array}$ & $\begin{array}{r}240 \\
10 \\
10 \\
2\end{array}$ & $\begin{array}{r}344 \\
60 \\
16 \\
15\end{array}$ \\
\hline & \multicolumn{5}{|c|}{ Soil under big bluestem } \\
\hline $\begin{array}{l}1 \mathrm{st} \ldots \ldots \\
2 \mathrm{~d} \ldots \ldots \\
3 \mathrm{~d} \ldots \ldots \\
4 \mathrm{th} \ldots .\end{array}$ & $\begin{array}{l}670 \\
244 \\
188 \\
188\end{array}$ & $\begin{array}{r}485 \\
20 \\
10 \\
19\end{array}$ & $\begin{array}{l}506 \\
164 \\
146 \\
118\end{array}$ & $\begin{array}{r}346 \\
8 \\
28 \\
23\end{array}$ & $\begin{array}{r}502 \\
109 \\
93 \\
87\end{array}$ \\
\hline
\end{tabular}

The soil was moist when the experiment was begun. The distance between the cylinders in a group was 4-14 inches, and the distance between the two areas of soil sampled was only 15 feet. Under big bluestem the first $250 \mathrm{cc}$. of water disappeared in 2-4 minutes in all four cylinders. In two of them a second 250 cc. disappeared within the first half-hour. During the first period the average rate of water infiltration was $46 \%$ more rapid under big bluestem. It was $82 \%$ more rapid during the second period. During the second hour, rates of infiltration were $481 \%$ and $480 \%$ greater, respectively, than in bluegrass sod. Thus, once the water reached the soil under the mulch, it entered it rapidly. 
EVAPORATION.-The relative rate of loss of water from soil with mulch removed and from that covered with a mulch of big bluestem was ascertained. Four pans, like those previously described but without holes, were used. Potting soil which had been thoroughly mixed was placed in each to a depth of about 2 inches. Equal amounts of water were then added until the soil was very wet and similar to that in the abandoned road in spring. Samples of mulch, cut to fit into the square-foot area of the container, were placed in each of two pans. Two other lots of soil were left unmulched. The pans were placed in a room before a large fan which created a continuous movement of air over them of about 6 miles per hour. Daily temperatures were about $70^{\circ} \mathrm{F}$. at night and $80^{\circ}-$ $95^{\circ} \mathrm{F}$. during the day. Humidity varied from 35 to $80 \%$. There was strong diffuse light by day.

Loss of water from the mulched soil during the first day averaged $75 \%$ less than that from unmulched soil. It was $43 \%$ less the second day. By the end of the third day the bare soil, which had lost a total of 1,187 gm. of water, was dry on the surface and began to crack. The mulched soil had undergone a total loss less than half this great. Losses from the mulched soil decreased gradually as it became drier. Total loss during the 8-day period was practically the same as that during the first 3 days from the unmulched soil.

In a similar experiment (July 26-28) the pans were exposed to both sun and wind from 8:00 A.M. to 7:00 P.M. A wooden frame protected the sides of the containers from the sun. The mulch was 2.5 inches thick in two containers; in the controls the soil was unmulched. Kind of soil and water content were the same as those in the preceding experiment. Both daily and total losses from the mulched soils were very similar. During the first day average water loss from the mulched soil was $74 \%$ less than that from the unmulched one, and the loss during the 3day period was $65 \%$ less.

PRECipitation AND WATER CONTENT of soIL.-During this study there was a good supply of soil moisture for plant growth at all times. Both the amount of

TABLE 5

TOTAL WATER CONTENT OF SOIL AT VARIOUS DEPTHS IN THE ABANDONED ROAD ON AUGUST 6, 1951

(Data from mulched soil are in parentheses)

\begin{tabular}{|c|c|c|c|}
\hline Community & $\begin{array}{c}0-6 \text { in. } \\
(\%)\end{array}$ & $\begin{array}{c}6-12 \text { in. } \\
(\%)\end{array}$ & $\begin{array}{c}12-24 \text { in. } \\
(\%)\end{array}$ \\
\hline Big bluestem. & $\begin{array}{c}22.6 \\
(25.9)\end{array}$ & $\begin{array}{c}20.9 \\
(19.7)\end{array}$ & $\begin{array}{c}22.9 \\
(18.8)\end{array}$ \\
\hline Switchgrass. & $\begin{array}{c}30.7 \\
(37.3)\end{array}$ & $\begin{array}{c}26.2 \\
(26.9)\end{array}$ & $\begin{array}{c}23.4 \\
(27.4)\end{array}$ \\
\hline Bluegrass. & 20.6 & 21.3 & 19.2 \\
\hline
\end{tabular}

precipitation and its frequency of occurrence were unusual. Monthly precipitation from April to September was 4.16, $4.69,11.94,3.58$, and 4.55 inches. Moreover, the rains were well distributed each month. The soil was wet to moist several feet in depth throughout the growing season. In the spring the total water content ranged from 23 to $27 \%$ in the surface foot to 21 to $22 \%$ in the second and third foot. In the fourth and fifth foot percentages were 17 and 15 , respectively. All but about 9\% was available for growth. Probably because of the unusually high rainfall, there were only minor differences in the total amounts of soil moisture in the mulched soil and in soil from which the mulch had been removed in early spring. Water content was also about the same under the grazed but untrampled bluegrass inside the fence (table 5). Soil samples were not 
taken to a greater depth than 2 feet because of great difficulty in withdrawing the geotome from the wet clayey soil.

Light AND TEMPERATURE.-Only 1$5 \%$ light penetrated through even the surface inch of the normally compacted mulch. Zero readings were practically always obtained with the Weston Sunlight Meter where it was placed deeper in the mulch. This explains the lack of green color in the basal 2-3 inches of the new shoots.

Soil temperatures at 0.5 -inch depth on a clear afternoon, May 7 , were $57^{\circ}$ and $59^{\circ} \mathrm{F}$. under the big-bluestem and switchgrass mulch, respectively, but $79^{\circ}$ and $82^{\circ}$ in plots with mulch removed in early spring. By May 22, when the air temperature was $71^{\circ}$ at 3:00 P.M. on a clear day, temperatures of $89^{\circ}$ and $63^{\circ}$, and $90^{\circ}$ and $62^{\circ}$ were found in the unmulched and mulched soil of big bluestem and switchgrass, respectively. Thus, early in May the upper soil was $22^{\circ}$ and $23^{\circ}$ colder under the mulch, but by May 22 the mulched soil was $26^{\circ}-28^{\circ}$ colder than that where the mulch had been removed. Readings on July 24 showed only small differences between unmulched and mulched big bluestem. The temperatures in the shade 3 inches above the bare soil, on the soil, and at depths of $1,3,6$, and 12 inches were $83^{\circ}, 79^{\circ}, 75^{\circ}, 74^{\circ}, 72^{\circ}$, and $68^{\circ}$, respectively. The temperature was $2^{\circ}$ lower over the mulch, $7^{\circ}$ lower on the mulched soil surface, and $4^{\circ}, 3^{\circ}, 2^{\circ}$, and $0^{\circ}$ lower at the several soil depths, respectively. Clearly, the heavy growth of grass had nearly counteracted the effects of heating where the mulch had been removed.

\section{EFFECT OF MULCH ON DEVELOP- MENT OF VEGETATION}

It seemed obvious that the effects of the mulch on the seasonal development of vegetation could best be ascertained by removing the mulch from sample areas and observing the results throughout the summer. On April 7, 1951, two plots in each type of vegetation were freed of their mulch. They will be designated hereafter as unmulched plots. Those in the big-bluestem and switchgrass types extended at right angles to the road or were limited to the upper half of the road and ran parallel with it. They were long plots, 12 feet wide and of sufficient area to furnish 50 square feet of vegetation for each of several harvests. Those in the prairie-dropseed type were smaller, since here comparison of growth was based upon a series of individual bunches. The mulch separated easily from the very moist soil. About oneeighth inch of humic mulch was left to protect the soil from too rapid drying. There was no new growth of vegetation, and any old attached stems were clipped close to the soil. There was no soft, compacted, rotting mass of vegetation. Even the lower part of the mulch was loose, friable, and well aerated.

EARLY GROWTH.-A month later, on May 7, no new shoots had appeared above ground under the mulch, but in the cleared places shoots of big bluestem were 1.5-2.5 inches tall, those of switchgrass 2.5-3.5 inches, and those of prairie dropseed 4.5 inches high.

Fifteen days later the unmulched plants were very leafy at the base. The lower leaves of big bluestem occurred at 1-1.5 inches above the soil. The plants were 6-7 inches tall, and each stem had three or four well-developed leaves. No leaves of the other group had appeared above the mulch. Although the shoots averaged 4 inches in height, practically no leaves were unfolded (figs. 6, 7). Nearly the same stages of development occurred in switchgrass, although the 
plants were somewhat taller. The shoots of unmulched prairie dropseed filled both the top and the sides of the elevated crowns almost completely. About 2.5 inches of mulch covered the crowns of the other group, but it was much deeper between the bunches. Here the new shoots were abundant only on the tops of the bunches, and none occurred elsewhere. There were about four leaves per stem on both unmulched and mulched bunches; the latter averaged 2 inches taller than the 8-inch-high, unmulched plants.

EARLY YIELD AND BASAL AREA.Sample lots of big bluestem and switchgrass were harvested on June 10 , each from a 50-square-foot sample in both unmulched and mulched plots. Leaves occurred 1-1.5 inches from the soil on the unmulched big bluestem but at 3-3.5

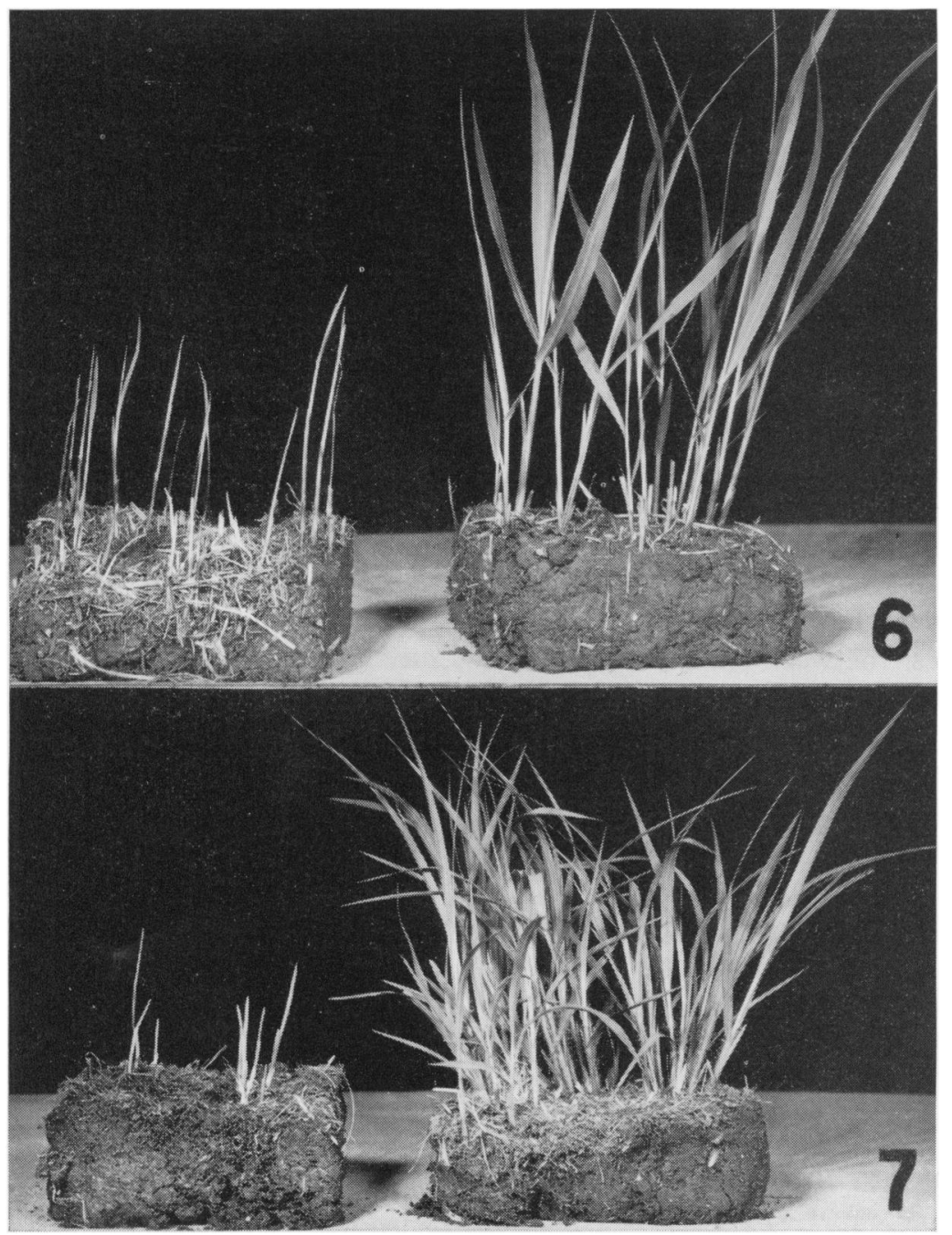

Figs. 6-7.-Fig. 6, representative sample of switchgrass from mulched and unmulched plots, May 23 1951. Fig. 7, similar samples of big bluestem. 
inches on the mulched plants. On switchgrass these heights were $2-3$ and 6-8 inches, respectively, except for the lower, scale-like leaf. After removing the mulch, each lot of grass was clipped to the soil surface. The old stems and debris in the mulched lot were then separated from the green ones of the current year. The green grass was air dried and weighed to the nearest gram. Big bluestem from the mulched plot weighed $53 \%$ less than that from the unmulched plot, and switchgrass $57 \%$ less. The lower weight must be attributed to the presence of the mulch. Water content of soil was continuously high, but the mulched soil was colder, and the light very low or nil in the mulch.

That the effects of the mulch had greatly thinned the stand was shown both by stem counts and measurement of basal area. In ten square-foot samples taken at random in pure stands of each grass the number of stems under the mulch was $39 \%$ lower for big bluestem and $38 \%$ less for switchgrass than in unmulched areas. Both grasses were more slender in the mulch.

Basal area was ascertained in a series of thirty-five square-foot random samples in the mulched big bluestem and a similar number in the unmulched plots. The grass was clipped to a height of 5 inches in the mulched samples, and the mulch was removed. Then the plants were clipped to a height of 1.5 inches, as in the plots without mulch, and the basal area at this level was measured. Basal area in the mulched plot was only $9 \%$; but that in the unmulched plot, where the leaves spread widely below the clipping level and stems were also more abundant, was $22 \%$.

Basal area of twelve bunches of unmulched prairie dropseed was ascertained; then the foliage was closely clipped. A dozen mulched bunches of the same basal area were also clipped, and the debris in and about them was discarded. Foliage of the mulched bunches was 2-3 inches taller than the 17 -inch general height attained by that of unmulched ones. Stem-counts of several bunches of similar size revealed that there were $18 \%$ more stems in those without a mulch. The dry weights of foliage of the twelve unmulched and twelve mulched bunches were 523 and 360 gm., respectively. Weight of foliage from the mulched bunches was thus $31 \%$ lower (table 6).

MIDSUMmer YIELDS.-A new lot of plants was clipped on July 15 from areas, each of 50 square feet. Big bluestem had not yet developed flower stalks; those of switchgrass were present in considerable numbers in the unmulched plots, but panicles had not appeared. Flower stalks were fewer and smaller in the mulched area. Heights and yields are shown in table 6 . Yields were $26 \%$ less in mulched big bluestem and 55\% less in mulched switchgrass than in unmulched.

LATE SUMMER YIELDS.-A second lot of bunches of prairie dropseed, eighteen each in the unmulched and mulched areas, was harvested on August 7. These were selected after measurements as at the preceding harvest. Basal area of bunches in each group varied from 20 to 56 square inches. Vegetative growth for the year had been completed. All but five of the unmulched bunches had produced flower stalks; in the mulched lot there were none. A total of 645 panicles were exserted, or nearly so, from the sheath, but some had not yet expanded widely. The unmulched bunches were noticeably more erect than the mulched ones, but the leaves of the mulched plants were longer, and the habit was more sprawling. Thus, the average stretched height in the above sequence was 22 and 25 inches. 
When the mulch was discarded and the air-dry plants were weighed, those from the mulched plots weighed $21.5 \%$ less than those without mulch (table 6).

On August 16, when the big bluestem in the unmulched area had developed its flower stalks and was in full bloom, an- lar areas where the mulch had been removed.

A fourth harvest in September was planned, but heavy rains lodged the grass. This, combined with much cloudy weather, resulted in decay of the lower leaves. It became almost impossible to

TABLE 6

AVERAGE HEIGHTS, AIR-DRY WEIGHTS, AND YIELD DIFFERENCES OF GRASSES IN MULCHED AND UNMULCHED PLOTS

(Numbers in parentheses are heights of flower stalks)

\begin{tabular}{|c|c|c|c|c|c|}
\hline \multirow{2}{*}{ Date } & \multicolumn{2}{|c|}{ UNMULCHED } & \multicolumn{2}{|c|}{ MULCHED } & \multirow{2}{*}{$\begin{array}{c}\text { YIELD } \\
\text { DIFFERENCE } \\
(\%)\end{array}$} \\
\hline & $\begin{array}{l}\text { Height } \\
\text { (in.) }\end{array}$ & $\begin{array}{c}\text { Weight } \\
\text { (gm.) }\end{array}$ & $\begin{array}{l}\text { Height } \\
\text { (in.) }\end{array}$ & $\begin{array}{l}\text { Weight } \\
\text { (gm.) }\end{array}$ & \\
\hline & \multicolumn{5}{|c|}{ Big bluestem } \\
\hline $\begin{array}{l}\text { June } 10 \ldots \\
\text { July } 15 \ldots \\
\text { Aug. } 16 \ldots\end{array}$ & $\begin{array}{l}11 \\
27 \\
30(66)\end{array}$ & $\begin{array}{l}1,158 \\
3,306 \\
4,118\end{array}$ & $\begin{array}{l}14 \\
25 \\
26(32)\end{array}$ & $\begin{array}{r}550 \\
2,436 \\
2,934\end{array}$ & $\begin{array}{l}52.5 \\
26.2 \\
28.8\end{array}$ \\
\hline \multirow{3}{*}{$\begin{array}{l}\text { June } 10 \ldots \\
\text { July } 15 \ldots \\
\text { Aug. } 16 \ldots\end{array}$} & \multicolumn{5}{|c|}{ Switchgrass } \\
\hline & $\begin{array}{l}18 \\
42 \\
-(62)\end{array}$ & $\begin{array}{l}1,057 \\
4,168 \\
6,044\end{array}$ & $\begin{array}{l}22 \\
42 \\
-(51)\end{array}$ & $\begin{array}{r}451 \\
1,898 \\
4,500\end{array}$ & $\begin{array}{l}57.3 \\
54.5 \\
25.5\end{array}$ \\
\hline & \multicolumn{5}{|c|}{ Prairie dropseed } \\
\hline $\begin{array}{l}\text { June } 10 \ldots \\
\text { Aug. } \quad 7 \ldots\end{array}$ & $\begin{array}{l}14 \\
18\end{array}$ & $\begin{array}{r}523 \\
2,365\end{array}$ & $\begin{array}{l}16 \\
16\end{array}$ & $\begin{array}{r}360 \\
1,856\end{array}$ & $\begin{array}{l}31.2 \\
21.5\end{array}$ \\
\hline
\end{tabular}

other lot of plants was harvested. The foliage height averaged 30 inches and that of the flower stalks 66 inches. Foliage height in the mulched bluestem was 4 inches less, and the scarce flower stalks with inflorescence still ensheathed were usually less than 36 inches tall. Average heights of the unmulched and mulched switchgrass were 62 and 51 inches. Development of the panicles is shown in figure 8 . The mulched big bluestem yielded $28.8 \%$ less and the mulched switchgrass $25.5 \%$ less (table 6 ) than that from simi- separate them from the old mulch. Moreover, the plants had completed vegetative growth by mid-August, when deterioration set in. Since only scattered flower stalks were produced, it is probable that the third harvest represented approximately the maximum yield. The area was grazed after September 1.

\section{Changes IN vegetation}

The vegetation in the abandoned road had matured, fallen, and decayed over a period of many years. There was little or 
no differentiation in its composition due to the ruts and ridges which, although still prominent, were entirely concealed by the dense stands of grass and the thick carpet of mulch. The nature of the original roadside prairie can be inferred only by comparison with vegetation on similar sites in adjacent prairie on other little-used roadsides. The vegetation was very different from that of mowed prairie, and these differences seem to have been the result of the accumulation of a large amount of debris and its effect upon the environmental conditions.

Big-Bluestem TYPE.-The most extensive type was the rank growth of big bluestem. It seems very probable that this species occurred as an intermixture of $15-18 \%$ with other vegetation on the uplands before the 7 years of great drought, 1934-40 (14). The much more abundant little bluestem (Andropogon scoparius) probably composed $50 \%$ of the vegetation, judging from conditions on similar nearby sites on the same slopes and soil type. But little bluestem lost heavily, often $95 \%$ of its population, during the drought. It has been widely observed during years of good rainfall (1941-1951) that big bluestem gradually thickened, often to nearly pure stands, and occupied much territory in which, before the drought, it had composed only a small part of the vegetation (12). Its great foliage height, 2.0-2.5 feet, and the tall dense stands of flower stalks, its deeper roots, and its sod-forming habit placed the bunch-forming little bluestem, prairie dropseed, and other lower-growing vegetation at a great disadvantage. The large amount of mulch that it produced when it was left ungrazed and unmowed was perhaps as great a detriment to the mid grasses as the shade of the current new growth.

The presence of the debris, both fallen and standing, acted favorably to the retention of snow and its accumulation when blown by the wind. The strip of thick mulch running at right angles to many of the slopes retarded the flow of runoff water from the heavily grazed pasture, while the deep ruts and high ridges

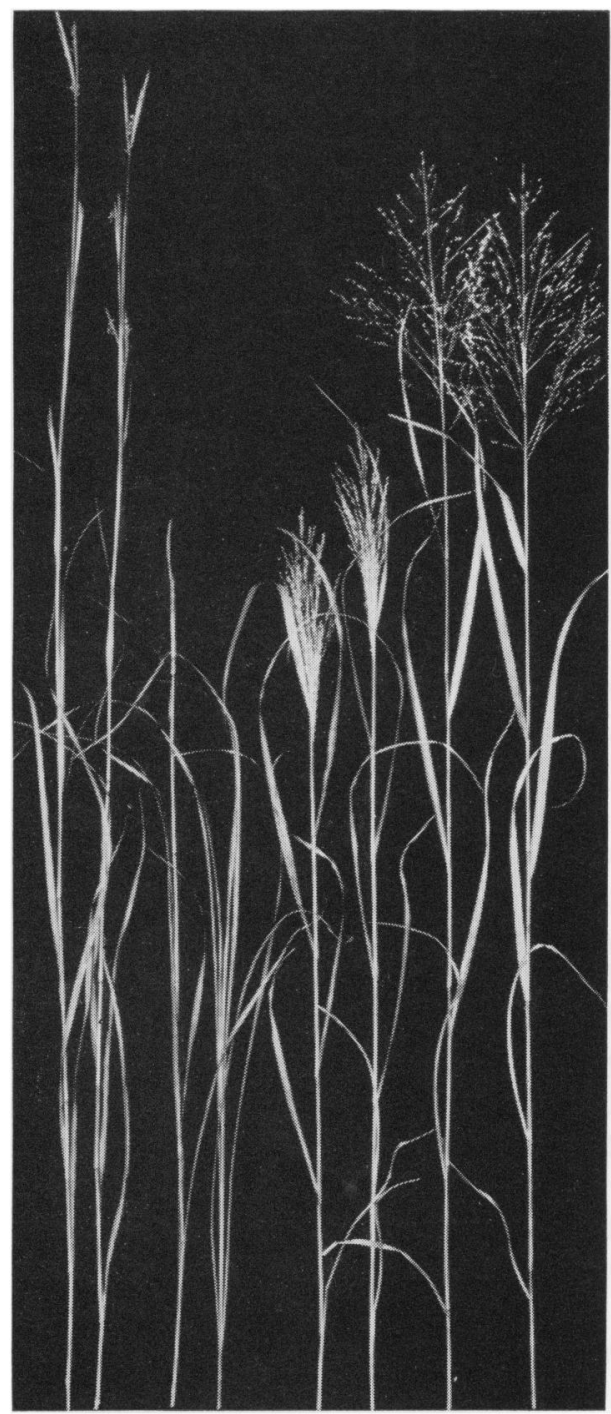

FIG. 8.-Average plants selected to illustrate differences in height and development, August 16, 1951. Big bluestem (left) and switchgrass (right) with expanded inflorescences are from unmulched plots. 
in the old road acted in many places as an effective barrier to water loss. That there was considerable run-in water was shown in a few places where eroded soil had been spread in the upper edge of this belt of tall grass, burying it and permitting the growth of ruderals.

The understory characteristic of upland prairie had all but disappeared. Such low-growing grasses and sedges as Bouteloua gracilis, B. hirsuta, Carex pennsylvanica, and C. meadii did not occur, and there were only small amounts of Panicum scribnerianum and $P$. wilcoxianumall characteristic plants of upland prairie. Forbs of the lower layer, as Antennaria campestris, Anemone caroliniana, and those with rosettes, as Hieracium longipilum, Senecio plattensis, and Erigeron ramosus, were absent. Astragalus crassicarpus and Sisyrinchium campestre were rare, and societies of Erythronium mesochoreum extremely reduced.

The mid grasses, Andropogon scoparius, Sporobolus asper, Stipa spartea, Bouteloua curtipendula, and Koeleria cristata, were absent or represented by only a few plants. The only forbs which were of sufficient abundance to form societies of considerable extent were $A$ morpha canescens, Aster multiflorus, Ambrosia psilostachya, Artemisia gnaphalodes, Helianthus rigidus, Solidago glaberrima, and Rosa pratincola. Nor did any of these, except the sage, display the flowers to a degree at all comparable with those in mowed prairie. Although about thirtyfive other species of forbs were present, none was plentiful.

Not until late June, when viewed from a distance, did the grayish tone of the winter aspect change to one of deep green. Moreover, by early August the aspect was entirely one of grass - the tall, dense stands of big bluestem, with a little Indian grass (Sorghastrum nutans) and switchgrass intermixed, overwhelmed other vegetation. In areas of several square yards scarcely another grass or forb occurred. A heavy crop of flower stalks, such as rather regularly occurs on lowlands, was produced in some places in 1949. In the drier summer of 1950 flower stalks were few; nor were they at all abundant in 1951. Switchgrass was adjacent to big bluestem on the moister side and to prairie dropseed on the drier one. But everywhere within its type big bluestem was the sole dominant.

SwITCHGRASS TYPE.- Switchgrass is typically found in habitats that are more moist than those occupied by big bluestem. It is less tolerant of shade than big bluestem, and it does not tiller so readily or so abundantly; but during the first half of the summer it is distinctly taller (14). It occurred in dense, pure, or nearly pure stands mostly on the north side of the road where accumulation of snow and, probably, the amount of run-in water were greatest. Where other tall grasses were found, these were sometimes wild rye (Elymus canadensis) but mostly big bluestem. It may be that switchgrass is gradually extending its area at the expense of big bluestem. A sprinkling of much attenuated bluegrass and Scribner's panic grass (Panicum scribnerianum) stretching up to 2 feet in height, or rarely a stalk of Indian grass, were the only other grasses associated with it. The occurrence of forbs was also greatly restricted. Rosa pratincola, Amorpha canescens, and Solidago glaberrima, which occurred sparingly, were probably relicts. Acalypha virginica occurred commonly and indicated a mesic habitat; Oxalis stricta also grew here. But the characteristic forbs were Galium aparine and Vicia americana. Galium was nearly confined to the habitat of the switchgrass type. It frequently occurred as dense 
patches, individual plants reaching a height of 2.0-2.5 feet. Vicia, commonly found in lowland or on banks of ravines, began growth early. By the first week in May it was 6 inches above the dense mulch and ultimately attained a height of 2 feet or more. Both species flourished in this shady, moist habitat until midsummer. Other prairie species were excluded from this heavily mulched, upland community. In a few places dense masses of debris had accumulated to a depth of 18-24 inches, so that no vegetation of any kind developed in 1951.

PRAIRIE-DROPSEED TYPE.-The occurrence and present distribution of the much less mesic prairie dropseed has been explained (12). It spread down the slopes from the drier upland sites often to the edge of ravines. The myriads of seedlings established during the least severe years of the drought rapidly grew into tufts and then into large bunches. Once a good stand was attained, other grasses and forbs had difficulty in becoming established. In some prairies this spreading continued until 1946.

Where the stand was pure, or even about single large bunches, the mulch was thick; other species were few or none. Heavily mulched spaces unoccupied by any other species were common. Thus, although the somewhat elevated bunches actually covered only $10-15 \%$ of the soil surface, other vegetation was largely if not entirely excluded. Three forbs were commonly found in this type-Amorpha canescens, Ambrosia psilostachya, and Artemisia gnaphalodes. Panicum scribnerianum was often present, but, in general, well-developed stands of prairie dropseed were conspicuous because of the scarcity of other vegetation.

There is some evidence that big bluestem is replacing prairie dropseed. It has been noted (12) that big bluestem, fol- lowing its recovery from drought, invaded areas occupied by this species, even growing up through the bunches. This tall grass overtopped the dropseed and hindered its growth by shading. The roots of this grass also penetrate deeper than those of the dropseed. The tendency toward more mesic conditions because of the mulch is favorable for this change in the vegetation.

MIXED-GRASS TYPE.-Composition of the vegetation in the mixed-grass community need not be discussed in detail. It probably represents the portion of the original vegetation least modified by complete protection. The mulch was thinner. Here one found not a single dominant grass but many mid-grass dominants, as Stipa spartea, Sporobolus asper, and Andropogon scoparius. There was a small percentage of Poa pratensis, Koeleria cristata, Eragrostis spectabilis, and Agropyron smithii in addition to variable amounts of grasses previously mentioned. There were many more species of forbs, and greater numbers as well, than in any of the preceding types. Lower, middle, and upper layers of vegetation were all represented, as were also representative species of each of the several seasonal aspects. This type more nearly approached the norm for True Prairie and thus, by contrast, made clear the changes in the vegetation that had occurred elsewhere.

\section{Discussion}

In their study of the prairies and pastures of the loess hills of central Nebraska, WeAver and Bruner (13) observed the unmowed prairie lying on the steep slopes between the flat-bottomed ravines and the rolling uplands. "On the sides of the ravines above the reach of the mower, the mulch of dead big bluestem was often 5 to 10 inches deep, since the 
prairie was rarely burned intentionally. In this debris, which was sometimes more than a foot deep, one could readily distinguish three crops of dead plants - two of decaying leaves and one of leaf moldunder the living grasses. This accumulation of material prevented the development of an understory, greatly delayed growth in spring, and thinned the new stand of bluestem or other tall grasses to about one-third the usual number of stems."

Hopkins (6), as a result of further study in the same area, stated: "Removal of this mulch in the spring resulted in an increase in basal area by the following autumn of at least threefold... . Total mulch had an average air-dry weight of over 15,000 pounds per acre, and as much as 19,000 pounds was present where conditions permitted the best development of vegetation.... This represented an accumulation of the growth of several seasons. ... The surface of the soil was always moist beneath the mulch even in the driest weather. Where the prairie was mowed annually there was an average of only 838 pounds of mulch [per acre] on the soil surface."

Amount of mulch in a relict area of climax prairie near Fort Worth, Texas, which had been unmowed and ungrazed for decades, was compared by DyksterHUIS and Schmutz (5) with that from a native hay meadow, on comparable soil. The meadow had been ungrazed for many years but mowed once annually in July. Both mulch and green herbage were obtained from three meter quadrats in each of the two grasslands. The mowed grassland yielded 1,938 pounds of air-dry organic mulch per acre; the undisturbed grassland had accumulated 9,037 pounds. The green herbage from the mowed prairie, however, was much greater $(1,033$ pounds) than that from the deeply mulched prairie (621 pounds). Thus, a decrease in forage production was associated with the heavier mulch.

Measurements of yield in the 290-acre pasture adjacent to the abandoned road gave similar results in 1950. Because of poor distribution of the grazing animals in this 50 -year-old prairie, about $12 \%$ of the area had been grazed so lightly that a dense mulch, 3-5 inches thick, had accumulated. In this portion not only was growth in spring greatly delayed and various species (including Kentucky bluegrass) more or less excluded but also the seasonal yield was considerably lower (18). This decrease was verified by further (unpublished) studies in 1951. Usually, however, increase in mulch is one of the indicators of potentially higher yields.

In drier climates an organic mulch may not accumulate in grassland in excessive amounts, even if the cover is undisturbed. For example, LARson and Whitman (7), working in the Mixed Prairie of southwestern South Dakota, reported forage yields which varied directly with the depth of the natural mulch. But here the virgin grassland, long protected from grazing and fires, had accumulated throughout the years a mulch which was only $0.25-0.5$ inch deep.

\section{Summary}

1. An upland prairie, undisturbed by mowing, grazing, or burning for 15 years, was studied. About $80 \%$ was covered with a nearly pure stand of Andropogon gerardi. Similar stands of Panicum virgatum and Sporobolus heterolepis each occupied about $9 \%$.

2. A dense natural mulch, $4.5-8$ inches deep and weighing 6-9 tons per acre, covered the deep loam soil. The mulch inter- 
cepted much precipitation but promoted more rapid infiltration of water which reached the soil and greatly retarded evaporation. It increased the organic matter of the surface soil $1.5-2 \%$ and nitrogen content $0.1 \%$ of its oven-dry weight.

3. Roots and rhizomes grew thickly below the mulch and mellowed the surface soil. Pore space was $61.7 \%$, and volumeweight was 0.97 .

4. Soil temperatures $22^{\circ}-28^{\circ} \mathrm{F}$. lower under the mulch in May delayed growth about 3 weeks compared with plants where the mulch had been removed. Production of flower stalks was considerably later in all mulched grasses and also less in Andropogon. Flower stalks were abundant on all unmulched grasses.
5. Yields in June, July, and August were 53, 26, and $29 \%$ less from mulched stands of Andropogon, and 57, 55, and $26 \%$ less in Panicum than those from unmulched stands.

6. Consequences of the effects of the mulch upon the environment were the production of a nearly pure, but somewhat thinner than normal, stand of $A n$ dropogon. The understory characteristic of upland prairie had all but disappeared. The usual mid grasses of upland were few or none. Only a few of the taller forbs remained.

7. Dense stands of Panicum with forbs characteristic of very moist sites were typical. Between the large bunches of prairie dropseed the deeply mulched soil was usually free of vegetation.

\section{LITERATURE CITED}

1. Association of Official Agricultural ChemISTs. Official Methods of Analysis. 7th ed., p. 13. 1950.

2. ClARK, O. R. Interception of rainfall by herbaceous vegetation. Science 86:591-592. 1937.

3. - - Interception of rainfall by prairie grasses, weeds, and certain crop plants. Ecol. Monog. 10:243-277. 1940.

4. Curtis, J. T., and Partch, M. L. Some factors affecting flower production in Andropogon gerardi. Ecology $31: 488-489.1950$.

5. Dyksterhuis, E. J., and Schmutz, E. M. Natural mulches or "litter" of grasslands: with kinds and amounts on a southern prairie. Ecology 28:163-179. 1947.

6. Hopkins, H. H. Ecology of the native vegetation of the loess hills in central Nebraska. Ecol. Monog. 21:125-147. 1951.

7. LARSON, F., and Whitman, W. A comparison of used and unused grassland mesas in the Badlands of South Dakota. Ecology 23:438-445. 1942.

8. Robertson, J. H. A quantitative study of TruePrairie vegetation after three years of extreme drought. Ecol. Monog. 9:431-492. 1939.

9. Sampson, H. C. An ecological survey of the prairie vegetation of Illinois. Illinois Nat. Hist. Surv. 13:523-577. 1921.

10. Shively, S. B., and Weaver, J. E. Amount of underground plant materials in different grass- land climates. Univ. Nebraska Conserv. and Surv. Div. Bull. 21. 1939.

11. Smith, H. W., and Weldon, M. D. A comparison of some methods for the determination of soil organic matter. Soil Sci. Soc. Amer. Proc. 5:177-182. 1940.

12. Weaver, J. E. Stabilization of midwestern grassland. Ecol. Monog. 20:251-270. 1950.

13. Weaver, J. E., and Bruner, W. E. Prairies and pastures of the dissected loess plains of central Nebraska. Ecol. Monog. 18:507-549. 1948.

14. Weaver, J. E., and Fitzpatrick, T. J. The prairie. Ecol. Monog. 4:109-294. 1934.

15. Weaver, J. E., and Flory, E. L. Stability of climax prairie and some environmental changes resulting from breaking. Ecology 15:333-347. 1934.

16. Weaver, J. E., and Hansen, W. W. Native midwestern pastures: their origin, composition, and degeneration. Univ. Nebraska Conserv. and Surv. Div. Bull. 22. 1941.

17. Weaver, J. E.; Hougen, V. H.; and Weldon, M. D. Relation of root distribution to organic matter in prairie soil. Bot. Gaz. 96:389-420. 1935.

18. Weaver, J. E., and Tomanek, G. W. Ecological studies in a midwestern range: the vegetation and effects of cattle on its composition and distribution. Univ. Nebraska Conserv. and Surv. Div. Bull. 31. 1951. 